\title{
Sero-prevalence of hepatitis $B$ virus and risk analysis of vertical transmission among pregnant women attending the obstetrics and gynecology hospital, Chennai (Tamilnadu), India
}

\section{Anusha Raaj ${ }^{1}$, Narayanasamy Krishnasamy ${ }^{2}{ }^{*}$, Karthick Rajendran ${ }^{3}$}

\author{
${ }^{1}$ Department of Obstetrics \& Gynaecology, Madras Medical College, Chennai, Tamil Nadu, India \\ ${ }^{2}$ Department of Hepatology, Madras Medical College, Chennai, India \\ ${ }^{3}$ Multidisciplinary Research Unit (MRU), Madras Medical College, Chennai, Tamil Nadu, India
}

Received: 13 November 2015

Accepted: 12 December 2015

\author{
*Correspondence: \\ Dr. Narayanasamy Krishnasamy, \\ E-mail: drkns_1963@yahoo.com
}

Copyright: () the author(s), publisher and licensee Medip Academy. This is an open-access article distributed under the terms of the Creative Commons Attribution Non-Commercial License, which permits unrestricted non-commercial use, distribution, and reproduction in any medium, provided the original work is properly cited.

\begin{abstract}
Background: Majority of the transmission of Hepatitis B viral infection occurs by vertical transmission from a carrier mother to infants. However, data regarding the seroprevalence of hepatitis B virus infection in pregnant women and risk factors associated with vertical transmission are lacking in India especially South India.

Methods: A cross-sectional, prospective study was conducted at Institute of Obstetric and Gynecology and Department of Hepatology, Madras Medical College, Chennai, Tamil Nadu, India. The study included of 2730 consecutive pregnant women and 160 cord blood samples of neonates of HBsAg positive mothers.

Results: The seroprevalence of HBsAg was found to be $5.86 \%$ among pregnant women. Vertical transmission was documented in $27.5 \%$ (44 of 160) of neonates born to mothers who were positive for HBsAg, it was highest in India reported anywhere. Although univariate analysis had shown the association of vertical transmission of HBV infection with maternal factors such as $\mathrm{HBeAg}$, HBV DNA, Infection status, anti-HBe and mode of delivery, Multivariate analysis had revealed that LSCS is independent risk factor $(\mathrm{OR}, 0.057 ; 95 \% \mathrm{CI}, 0.010-0.312 ; \mathrm{P}<0.001)$ for vertical transmission.

Conclusions: Prevalence of HBV in pregnant women was found to be high compared to general population reported earlier. LSCS had independent risk factor on vertical transmission than any other risk factors. Therefore, LSCS may not be advisable in HBsAg-positive pregnant women to prevent vertical transmission of HBV.
\end{abstract}

Keywords: Seroprevalence, Hepatitis B virus, Vertical transmission, Lower segment cesarean section

\section{INTRODUCTION}

Hepatitis B viral infection is most important infectious diseases throughout the world particularly in developing countries. According to WHO, globally more than 240 million people are affected with chronic hepatitis B liver infections, Of these, an estimated about 7.8 million people die yearly due to the acute or chronic consequences of hepatitis B. ${ }^{1}$ However, the epidemiology pattern and consequence of $\mathrm{HBV}$ and $\mathrm{HCV}$ infections varies greatly from one part of the world to another and changes in the time course. ${ }^{2}$
HBV infection affects a large number of women of reproductive age throughout worldwide. In India, the prevalence rate of HBsAg positivity in pregnant women varies from $0.9 \%$ and $11.2 \% .^{3-5}$ However, there is a scarcity of systematic information on the prevalence of HBV infection among pregnant women in India including the study area. Screening and evaluation of hepatitis during the pregnancy is much more important to prevent mortality of mother and child. This will be useful to address the current prevalence status of hepatitis during pregnancy. 
Hepatitis $\mathrm{B}$ virus infection may be transmitted by the parenteral and percutaneous routes, through sexual intercourse, during labor and by perinatal vertical route from an infected mother. One of the main cause of the transmission of Hepatitis B in India occurs due to vertical transmission from virus infected carrier mother to the baby. ${ }^{6}$ Transmission of HBV from mother to child stays a serious public health problem. Not only do these carriers become victims of a chronic disease but they serve as reservoirs of $\mathrm{HBV}$, which are transmitted to neonates.

Transmission of HBV can occur mainly during and soon after delivery, through direct contact of the infant with infectious mother's blood and other body fluids. ${ }^{7}$ Chronic infection occurs in $90 \%$ of virus infected children in the neonatal stage, particularly those whose mothers positive with $\mathrm{HBsAg}$ and $\mathrm{HBeAg}$ positive at birth. However, the transmission of infection depends on carrier mother's other factors, positivity of circulating HBV DNA, acute infection status, positivity of anti-HBe, and mode of delivery.

Data on the exact prevalence of $\mathrm{HBV}$ infection in pregnant women and factors depends on maternal transmission (vertical transmission) of the virus in South India are lacking, which has an important role in the prevention and monitoring of people with the disease. Hence the aim of this study is to estimate the seroprevalence of HBV infection in pregnant women in Chennai based populations, South India and to determine the risk of perinatal transmission and possible risk factors associated with infections in pregnant women positive for HBsAg.

\section{METHODS}

\section{Study population}

This prospective study was carried out at Institute of Obstetric and Gyneacology associated Madras Medical College in collaboration with the Department of Hepatology, Madras Medical College, Chennai, Tamil Nadu, India. The study period was conducted from December 2010 to November 2011 and the study population included of 2730 consecutive pregnant women of any trimester of pregnancy attending the antenatal clinic of the above hospital, sample size was determined using online tool http://www.openepi.com/Menu/OE_Menu.htm.

\section{Data collection}

All pregnant women were screened for HBsAg by ELISA method. Women who tested HBsAg positive were enrolled in the follow up study up to delivery. Demographic details, history of risk factors, chronic hepatitis and obstetric history was obtained. At the time of admission for delivery of positive cases, again a history was taken, rechecked with the previous details and also the data on mode of delivery, weight and maturity of babies at delivery was obtained. The Institutional Ethics Committee approved the study and informed consent was obtained from all the study subjects prior to screening and enrollment in the study.

\section{Sample collection and analysis}

$2 \mathrm{~mL}$ blood samples were collected from women for the first time during that particular pregnancy, irrespective of duration of gestation. Screening of HBsAg was detected by Hepanostika Test kit (ELISA) method. Hepanostika uniform II is a ELISA based on a one step 'sandwich' principle. Cord blood was collected at the time of delivery of the HBsAg positive women and tested for HBsAg; positive of HBsAg in cord blood was taken as evidence of vertical transmission of $\mathrm{HBV}$.

\section{Data analysis}

All the data collected were entered in MS EXCEL sheet. Analysis was done by using SPSS 20.0 (statically packages for social sciences 20 software), SPSS, Inc., Chicago, IL. Quantitative data were expressed as mean \pm SD or percentage. Qualitative data were analyzed by Chisquare test. Univariate and Multivariate logistic regression analysis were performed for odds ratio with 95\% confidence intervals and statistical significance was assessed at level of $\mathrm{P}<0.05$.

\section{RESULTS}

2772 pregnant women were chosen consequently as the study populations. Before completing questionnaires, providing blood samples, or conclusive serological results, 42 individuals were excluded. The mean age of participants was $25.57 \pm 3.571$ years.

\section{HBsAg prevalence rate}

Total of 2730 pregnant women were screened for hepatitis B surface antigen from December 2010 to November 2011, of the 2730 women screened, 1228 $(44.98 \%)$ were from urban sector and 1502 (55.02\%) were from sub-urban and rural sectors. A majority of women belonged to low socio-economic class i.e. class 4 $(1144 ; 41.9 \%)$ and class $5(1583 ; 57.98 \%)$, only 3 women belonged to middle class according to revised Kuppuswamy's scale.

Seroprevalence of HBsAg was found to be $5.86 \%$ (160/2730). The highest prevalence of $\mathrm{HBsAg}$ was observed in the age group 21-25 yrs $(82 / 1082 ; 7.58 \%)$ followed by $26-30 \mathrm{yrs}(45 / 864 ; 5.21 \%)$ and lowest in the age group $>35$ yrs $(3 / 91 ; 3.29 \%)$. The difference in HBsAg prevalence rate in different age groups was statistically significant with $\mathrm{P}<0.01$. 


\section{Vertical transmission or mother-to-child transmission rates}

Vertical transmission among infant was tested by cord blood HBsAg positivity at birth. Vertical transmission was occurred in (44 of 160) $27.5 \%$ of infants among the HBsAg positive women (Table 1).

Table 1: Clinical characteristics of mothers.

\begin{tabular}{|c|c|c|c|c|}
\hline $\begin{array}{l}\text { Vari- } \\
\text { ables }\end{array}$ & $\mathbf{n}(\%)$ & $\begin{array}{l}\text { Infants } \\
\text { HBsAg } \\
\text { (Negative) } \\
(\mathrm{N}=120)\end{array}$ & $\begin{array}{l}\text { Infants } \\
\text { HBsAg } \\
\text { (Positive) } \\
(\mathrm{N}=40)\end{array}$ & P Value \\
\hline \multirow{2}{*}{$\begin{array}{l}\mathrm{HBe} \\
\mathrm{Ag}\end{array}$} & Positive & $\begin{array}{l}17 \\
(42.5 \%)\end{array}$ & $23(57.5 \%)$ & \multirow[t]{2}{*}{$<0.001$} \\
\hline & Negative & $99(83.5 \%)$ & $21(17.5 \%)$ & \\
\hline \multirow{2}{*}{$\begin{array}{l}\text { HBV } \\
\text { DNA }\end{array}$} & Detectable & $\begin{array}{l}18 \\
(40.9 \%)\end{array}$ & $26(59.1 \%)$ & \multirow{2}{*}{$<0.001$} \\
\hline & $\begin{array}{l}\text { non- } \\
\text { detectable }\end{array}$ & $\begin{array}{l}98 \\
(84.5 \%)\end{array}$ & $18(15.5 \%)$ & \\
\hline \multirow{2}{*}{$\begin{array}{l}\text { Infect } \\
\text { ion } \\
\text { status }\end{array}$} & Acute & $8(44.4 \%)$ & $10(55.6 \%)$ & \multirow{2}{*}{$<0.009$} \\
\hline & Chronic & $\begin{array}{l}108 \\
(76.1 \%)\end{array}$ & $34(23.9 \%)$ & \\
\hline \multirow{2}{*}{$\begin{array}{l}\text { anti- } \\
\mathrm{HBe}\end{array}$} & Positive & $\begin{array}{l}57 \\
(98.3 \%)\end{array}$ & $1(1.7 \%)$ & \multirow{2}{*}{$<0.001$} \\
\hline & Negative & $\begin{array}{l}59 \\
(57.8 \%)\end{array}$ & $43(42.2 \%)$ & \\
\hline \multirow{2}{*}{$\begin{array}{l}\text { Mode } \\
\text { of } \\
\text { Deli- } \\
\text { very }\end{array}$} & LSCS & $\begin{array}{l}17 \\
(45.9 \%)\end{array}$ & $20(54.1 \%)$ & \multirow{2}{*}{$<0.001$} \\
\hline & VD & $\begin{array}{l}99 \\
(80.5 \%)\end{array}$ & $24(19.5 \%)$ & \\
\hline
\end{tabular}

\section{HBeAg antigen positive on vertical transmission}

Pregnant women with $\mathrm{HBeAg}$ positivity are at high risk for vertical transmission; hence we also performed a risk analysis on infants born to $\mathrm{HBeAg}$ positive pregnant women. Among $160 \mathrm{HBsAg}$ positive pregnant women, $40 \mathrm{HBeAg}$-positive women $(25 \%)$ were identified. Vertical transmission was occurred in $57.5 \%$ (23 of 40) of infants who were born to $\mathrm{HBeAg}$ positive women. There was significant statistical difference of vertical transmission rates between infants in the $\mathrm{HBeAg}$ positive women and the HBeAg negative women $(\mathrm{P}<0.001)$.

\section{Detectable HBV DNA on vertical transmission}

Of the $160 \mathrm{HBsAg}$-positive pregnant women, 44 (27.5\%) had detectable HBV DNA. Of those with detectable HBV DNA, perinatal transmission was identified in 26/44 infants $(59.1 \%)$. HBV DNA positivity was strongly correlated with vertical transmission $(\mathrm{P}<0.001)$.

\section{Anti-HBe positive on vertical transmission}

The anti-HBe-positive rate appears to a decreased risk for vertical transmission. We analyzed the pregnant women of positive to anti-HBe and $\mathrm{HBV}$ transmission to infants. Among the 58 cases with anti-HBe-positive, only 1 samples showed the transmission of $\mathrm{HBV}(1.72 \%, \mathrm{P}$ $<0.001)$. These results suggest that the presence of anti$\mathrm{HBe}$ in pregnant women could increase the protection of infants for transmission of HBV from mother.

\section{Infection status (acute or chronic) on vertical transmission}

Of the 18 acutely infected patients, 10 (55.6\%) infants were affected. $14(58.33 \%)$ infants were affected among the chronic infection group. The difference in transmission among babies in the various serological groups was statistically significant with a $\mathrm{P}$ value $<0.009$.

\section{Mode of delivery on vertical transmission}

On the basis of delivery modes, 123 out of the 160 positive women $(76.875 \%)$ delivered normally (vaginal delivery-VD). 37 mothers (23.125\%) underwent lower segment caesarean section (LSCS) all for obstetrical indications. Higher rate of vertical transmission was observed among infants in the LSCS group (20, 54.1\%) compared with vaginal delivery group $(24,19.5 \%)$, (P $<0.001)$.

Table 2: Logistic regression analysis of risk for vertical transmission of HBsAg.

\begin{tabular}{|c|c|c|c|}
\hline Variables & OR & $95 \% \mathrm{CI}$ & P value \\
\hline \multicolumn{4}{|c|}{ Univariate analysis } \\
\hline \multicolumn{4}{|c|}{ HBV DNA detectable: } \\
\hline No & $\mathrm{R}$ & - & - \\
\hline Yes & 0.127 & $0.058-0.278$ & $<0.001$ \\
\hline \multicolumn{4}{|c|}{ HBeAg Positive: } \\
\hline No & $\mathrm{R}$ & - & - \\
\hline Yes & 0.157 & $0.072-0.343$ & $<0.001$ \\
\hline \multicolumn{4}{|c|}{ Mode of Delivery: } \\
\hline VD & $\mathrm{R}$ & - & - \\
\hline LSCS & 0.206 & $0.094-0.452$ & $<0.001$ \\
\hline \multicolumn{4}{|c|}{ Infection status: } \\
\hline Chronic & $\mathrm{R}$ & - & - \\
\hline Acute & 0.252 & $0.092-0.689$ & $<0.007$ \\
\hline \multicolumn{4}{|l|}{ anti-HBe } \\
\hline Negative & $\mathrm{R}$ & - & - \\
\hline Positive & 41.542 & $5.534-311.836$ & $<0.001$ \\
\hline \multicolumn{4}{|c|}{ Multivariate analysis } \\
\hline $\begin{array}{l}\text { Mode of } \\
\text { Delivery }\end{array}$ & 0.057 & $0.010-0.312$ & $<0.001$ \\
\hline
\end{tabular}

OR- odds ratio; CI- confidence interval, R- Referral $\mathrm{p}=0.05, \mathrm{p}=0.01$, is given with the statistical significance 
Univariate analysis (Table 2) was revealed, all the risk factors such as $\mathrm{HBeAg}$, HBV DNA, Infection status, anti$\mathrm{HBe}$, and mode of delivery were significantly associated with vertical transmission of HBV. However, the multivariate model was revealed, only the mode of delivery especially the LSCS were independently associated with higher risk (OR, 0.057; 95\% CI, 0.010 $0.312 ; \mathrm{P}<0.001)$ for vertical transmission than any other risk factors.

\section{DISCUSSION}

Vertical transmission from mother to infant is a major route of transmission for hepatitis B virus infection. Hepatitis B infected infants will have an about $90 \%$ risk for developing chronic HBsAg carriage and chronic liver disease. Moreover immunization of affected infants will have an interrupt due to this vertical transmission. There is an emergency to undertake a necessary initiation to look into the possible ways to prevent and also to treat the vertical transmission. We took the first systematic large sample study on Hepatitis B virus infection among pregnant women and its vertical transmission in the southern region of India, Chennai.

In this study the seroprevalence of HBsAg among pregnant women was found to be $5.86 \%$. Seroepidemiological studies of different populations show variations in the prevalence such as Sehgal A et al reported $2.6 \%$ prevalence, Nayak et al $(3.7 \%)$, gill et al (5.0\%) (10), Prakash et al. observed $9.5 \%$ prevalence rates. $^{8-11}$ The HBsAg positivity in antenatal pregnant women in India ranges from 1 to $12.3 \%$ with a mean of $4.22 \%$. But the prevalence of this study among Chennai based population slightly above of mean among the Indian subjects with respect to pregnant women. These differences can be attributed to various factors like type of population studied, geographical region, genetic factors and socio economic conditions. A significant difference and increase in prevalence rate was observed among the seropositive group as reported in many other Indian studies except for the Prakash et al., where a high prevalence was observed.

Significant result of this study is vertical transmission rate. which have not been documented by the many studies in India, however, vertical transmission rate was relatively high when compared to the other reported study from New Delhi, we found that the vertical transmission was (44/160) $27.5 \%$ of infants among the HBsAg positive women. $^{12}$

The risk factors associated with vertical transmission of HBV infection have been analyzed in detail in this study. The factors associated with HBV transmission such as HBeAg, HBV DNA, Infection status, anti-HBe, and mode of delivery have been identified in this study, very few studies in India have studied these factors association to vertical transmission.
$\mathrm{HBeAg}$ positivity rate among $\mathrm{HBsAg}$ positive antenatal women have shown geographical variations in different parts of India as reported by Shenoy et al. HBeAg positivity in our study was $40(25 \%)$ and vertical transmission rate $23(57.5 \%)$ was significantly higher among infants born to $\mathrm{HBe} \mathrm{Ag}$ positive mothers compared to $\mathrm{HBeAg}$ negative mothers. $\mathrm{HBeAg}$ positivity in antenatal mothers increases the risk of vertical transmission and it was significantly correlated with vertical transmission of $\mathrm{HBV}$ in univariate logistic regression. This has showed significant higher rates of transmission among the $\mathrm{HBeAg}$ positivity mothers. The vertical transmission rate was $26(59.1 \%)$ in infants born to HBV DNA detectable mothers whereas in HBV DNA non-detectable mothers was $18(15.5 \%)$ indicates a potential for the increased transmission in this HBV DNA detectable population. Although we did not evaluate the HBV DNA level, our data pointed in the direction of HBV DNA positivity test performing in HBsAg positive women during the pregnancy to prevent transmission in highly viremic mothers.

Several studies in different population have demonstrated that maternal negative to anti-HBc before delivery was the most important independent risk factor for vertical transmission. Of the 58 mothers with positive to anti$\mathrm{HBc}$, only $1(1.7 \%)$ was transmitted the infection at the time of delivery, which showed that anti-HBc positive mothers was reduced the vertical transmission of HBV infection. Mothers who were at acute stage transmitted infection to the babies more than the mothers infected in chronic stage. A significant association between chronic and acute stage of infection on vertical transmission was observed in our study. This once again proves that the identification of stage of infection is a more sensitive indicator of vertical transmission. Transmission of HBV infection during delivery is the most frequent method of vertical transmission. It happens mostly due to infants contact with the mother's infected secretions or blood at the time of delivery. As evident from our study on vertical transmission of $\mathrm{HBV}$, women deliver infants through LSCS method are at high risk of spreading the Hepatitis B viral infection than other risk of $\mathrm{HBV}$ transmission, hence we recommend that performing of LSCS in positive with HBsAg may be advisable to vaginal delivery or more careful procedure to prevent vertical transmission.

\section{CONCLUSIONS}

In conclusion, our study demonstrated that a significantly higher vertical transmission rate was observed in infants delivered by pregnant women in our region when compared with the other population. Compared with VD, LSCS showed higher rate of vertical transmission.

\section{Limitation of the study}

We have not done the viral load of the positive cases. We have not follow-up in both mothers and infants for certain 
period of time in order to morbidity and mortality complications.

\section{ACKNOWLEDGMENTS}

We sincerely thank the participants who contributed to this work.

\section{Funding: No funding sources}

Conflict of interest: None declared

Ethical approval: The study was approved by the Institutional Ethics Committee

\section{REFERENCES}

1. WHO, Hepatitis B, Fact sheet $\mathrm{N}^{\circ} 204$. Available at http://www.who.int/mediacentre/factsheets/fs204/en. Accessed 01 November 2015.

2. Te HS, Jensen DM. Epidemiology of hepatitis B and C viruses: a global overview. Clin Liver Dis. 2010;14(1):1-21.

3. Tandon BN, Acharya SK, Tandon A. Epidemiology of hepatitis B virus infection in India. Gut. 1996;38:556-9.

4. Dwivedi M, Misra SP, Misra V, Pandey A, Pant S, Singh R. Seroprevalence of hepatitis B infection during pregnancy and risk of perinatal transmission. Indian J Gastroenterol. 2011;30:66-71.

5. Prakash C, Sharma RS, Bhatia R, Verghese T, Datta KK. Prevalence in North India of hepatitis B carrier state amongst pregnant women. Southeast Asian J Trop Med Public Health. 1998;29:80-4.

6. Trehanpati N, Hissar S, Shrivastav S, Sarin SK. Immunological mechanisms of hepatitis B virus persistence in newborns. Indian $\mathrm{J}$ Med Res. 2013;138:700-10.

7. WHO, Update No. 22, November 1996, Available at http://www.who.int/maternal_child_adolescent. /documents/pdfs/hepatitis_b_and_breastfeeding.pdf. Accessed 01 November 2015.

8. Sehgal A, Gupta I, Sehgal R, Ganguly NK. Hepatitis $B$ vaccine alone or in combination with anti-HBs immunoglobulin in the perinatal prophylaxis of babies born to HBsAg carrier mothers. Acta Virol. 1992; 36:359-66.

9. Nayak NC, Panda SK, Zuckerman AJ, Bhan MK, Guha DK. Dynamics and impact of perinatal transmission of hepatitis B virus in North India. J Med Virol. 1987;21:137-45.

10. Gill HH, Majumdar PD, Dhunjibhoy KR, Desai HG Prevalence of hepatitis $\mathrm{B}$ e antigen in pregnant women and patients with liver disease. J Assoc Physicians India. 1995;43:247-8.

11. Prakash C, Sharma RS, Bhatia R, Verghese T, Datta KK. Prevalence in North India of hepatitis B carrier state amongst pregnant women. Southeast Asian J Trop Med Public Health. 1998;29:80-4.

12. Chakravarti A, Rawat D, Jain M. A study on the perinatal transmission of the hepatitis B virus. Indian Journal of Medical Microbiology. 2005;23(2):12830 .

Cite this article as: Raaj A, Krishnasamy N, Rajendran K. Sero-prevalence of hepatitis B virus and risk analysis of vertical transmission among pregnant women attending the obstetrics and gynecology hospital, Chennai (Tamilnadu), India. Int J Reprod Contracept Obstet Gynecol 2016;5:170-4. 